\title{
Factors Influencing the Consumer's Intention of Buying through Facebook - A Study on Dhaka City
}

\author{
Shakila Jahan Nipa, Fahmida Akter, and Mohammed Shakhawat Hossain
}

\begin{abstract}
Now a day social media is used as a platform to not only creates relationship but also it is the powerful implements of marketing communication which is sharply changed the traditional marketing approach. This paper is based on the assumption of the influence of Facebook on changing the buying behavior of the consumer. A structured questionnaire consisting with a set of close-ended questions was developed to collect data. Data were collected from 156 respondents who have an experience of buying through Facebook. It is a causal type of research and PLS-SEM technique was used to analyze the collected data. The study identified that both security $\&$ privacy has positive influence to trust and ease of use \& usefulness also has positive influence to build attitudes towards Facebook. Finally, trust and attitudes towards Facebook to drive the intention of buying through Facebook.
\end{abstract}

Index Terms - Facebook, buying behavior, marketing communication

\section{INTRODUCTION}

Social media takes us back to the beginning when people lived in groups and took decisions together by nature affected by each other. By simple definition, the social media refers to activities, practices, and behavior among communities of people who gather online to share information, knowledge, and opinions using conversational media (Web-based applications) [49]. It can be defined as "consumer-generated media that covers a wide variety of new sources of online information, created and used by consumers intent on sharing information with others regarding any topic of interest" [27].

According to Zarella, there are some types of social media, like: Blog, Microblog (Twitter), Social Networks (Facebook, LinkedIn), Media sharing (YouTube, Flickr), Social News and Bookmarking (Digg, Reddit), Rating and reviews pages (Yelp), Forums and Virtual Worlds (Second Life) [58]. Using them has numerous benefits for consumers, such as: saving consumers time, betterinforming opportunities, more reliable information, reduced cost of informing, better communication with companies, and reduced prices. Almost half of the world's population used the Internet and social media, this trend is rapidly rise.

Published on July 22, 2016.

Shakila Jahan Nipa, Daffodil Institute of IT, Bangladesh.

(e-mail: Shakilajahan_nu@diit.info).

Fahmida Akter, Daffodil Institute of IT, Bangladesh.

(e-mail: fahmida_nu@diit.info).

Mohammed Shakhawat Hossain, Principal Daffodil Institute of IT, Bangladesh.

(e-mail: author@nrim.go.jp).
Among them Facebook is one of the most popular social networking sites which provide users with a platform to create personal profile pages add friends and send messages. Since the company was founded in February 2004 by Mark Zuckerberg, it has become the top-ranked social networking site [24].

Increasing use of social media worldwide has led to the belief that this is a valuable tool in supporting consumer engagement. Companies are continually looking to new methods for reaching consumers and for shaping consumer behaviors, including brand loyalty and intention to buy. The changing technological era has led to increased activity in social network platforms like Facebook, YouTube and Twitter, all of which have created mechanisms through which consumers can develop rapport and create interactions with brand-specific content [41]. Also, advertising and promotion often focus on the psychological, emotional, and social factors influencing consumer behaviors, elements that must be incorporated into technology-based marketing [42]. Marketing communication using social media such as Facebook has already been evaluated as a long-term trend and defined as a series of technological innovation [6]. It is possible to build a strong linked between companies and customers [46] by social media and it has created communication between users in the virtual relationship and get leverage effect with "likes,', "share," and "comments," [3] when they receive the advertisement from other users. It is extensively believed that youths dominate Facebook accounts and they perceived it is a good channel for advertisements of youth-oriented products. [50]. Other researcher said that Facebook is a social media tool used by many businesses to communicate with the most reasonable cost to the consumer [37].

\section{LITERATURE REVIEW}

In the present day communities of online and social networking sites (SNS) are increase the interactions and sharing information by web technology [29]. Modern consumers have the scope to get different information at low cost [51]. Social media is a key tool of marketing to increase the consumer's involvement [19]. The expansion of social media developed strategies of marketing by trust building and create the intension of online buying [30]. Different social media platform provide free online services for user to collaborate on shearing of information [8]. These platforms help to review and rating, creating new communities through electronic network where individuals can shear the information globally and quickly [31]. Social media is opening a new window in e-commerce which 
provides the instruction to consumer (Aaili 2013). Markets and any individual can easily post different contents such as, information, experiences and quality of the product [8]. Some users are very much sensitive for deciding to purchase by watch the review [8]. Different survey projected that the online comments creates both informational and emotional support [7]. Individuals search information through social media because they found other individual's interaction by internet which is useful to make purchase decision [14]. Online forums, communities, rating, reviews and recommendations all of them facilitated the purchase decision through Facebook or other online platform [20]. Purchase through the online, companies offer by websites and social networking pages for overcome the uncarting as the traditional shop replaced by a system impersonal storefront [20]. The statistics showed in year 2015, one third of the world's population engage with social media as the platform of consumer voice [37]. Producer use different strategy to induce the final consumer because consumer behavior very much influence by reference group [15]. As a marketing tool social media marketing going popularity and connecting people around the world due to its wide reach, economic characteristics and build relationship among the consumers [48]. The post purchase behaviors like satisfactions and dissatisfactions can be shared with others i.e. reaction process is direct in social media [33]. The Facebook crate a revolution in online communication environments in compare to traditional communication [26]. The cultural aspects have an influence to change the purchase intention either through online or from traditional way [39]. The advertisements in Facebook have strong effects on the buying behavior. But, eventually it depends on the opinions expressed by the students and their freedom [16]. The purchase intention of consumer influence by two factors one is shares from Facebook application and another electronic word of mouth communication [56]. Art of advertising creates a brand perception in consumer's minds that change the buying behavior and improve consumer engagement in social media [41].

Information search and evaluation of alternatives has the greatest influence to build attitudes towards social network that will change consumer's purchase decision [36]. Sometimes word of mouth and opinion given by people is more influential than the brand image in social media [43]. The users influenced positively to purchase decision use of like button, based check-in services and shear button but posting comments on social media shows no significant effect on purchase decision. Currently, many retailers still lack any real integration between their own web channel and social media despite the proliferation of 'like' buttons [45].

\section{ObJEctive Of The STUdy}

The main objective of this research paper is to examine the factors influencing the Consumer's intention of buying through Facebook and to make some strategic recommendations for companies and consumers on social media.

\section{MATERIALS AND Methods}

\section{A. Theoretical Framework}

This study is conducted based on the framework of Ajzen and Fishbein's Theory of Reasoned Action (TRA) or Theory of Planned Behavior (TPB) [1]. Also, TAM is an adaption of the Theory of Reasoned Action (TRA) and was used to assess user's computer acceptance, which is measured by the intention and the influence of attitude, perceived usefulness, perceived ease of use toward the intention to use [11]. The result showed that perceived usefulness strongly influenced intention to use but perceived ease of use only has a trivial effect on the intention to use. On the other hand, attitude partially mediated the effects of perceived usefulness and ease of use on an intention to use [11]. Since attitude did not play as an important determinant to influence the variables, TAM was then modified by removing the attitude variable found in TRA. The new TAM demonstrated the intention as a mediator to influence the relationship between perceived usefulness, perceived ease of use and usage behavior [53]. The result showed that perceived usefulness and perceived ease of use are determinants of intention to use. This was supported by several previous studies [20], [22], [23], [40], [28]. A related study by [13], [47], [57] found that perceived usefulness is an important determinant of intention to use, but perceived ease of use has an insignificant influence on intention to use. Bagozzi [4] urged that TAM model is not appropriate to investigate and explain usage behavior because perceived usefulness and perceived ease of use might not properly examine usage behavior. The supported study by Chuttur [10] suggested that future research should investigate and develop new models that focus on the strengths of the TAM and abandon its weaknesses.

\section{B. Hypothesis}

H1a: Privacy is positively related with trust.

H1b: Security is positively related with trust.

$\mathrm{H} 2 \mathrm{a}$ : Ease of use is positively associated with attitudes towards Facebook.

$\mathrm{H} 2 \mathrm{~b}$ : Usefulness is positively associated with attitudes towards Facebook.

H3: Trust positively influences the consumer buying behavior.

H4: Attitudes towards Facebook positively influence the consumer buying behavior.

\section{Types of Research \& Data Collection}

This is a causal research. This research employed deductive approach. A theoretical framework has been developed based on the literature review. In this research, both types of primary and secondary data were used to fullfill the research problems. Primary data were collected through a structured survey questionnaire. Accordingly, all the scale items for this study have been hired from prior research. The questionnaire was developed with a set of close-ended questions using a five-point Likert scale from Strongly Agree (5) to strongly disagree (1). Secondary data were collected from books, journal, newspapers, and websites through both electronic and print library as well as an internet search engine. Respondents who were lived in Dhaka city and have an experience of purchase products from online via Facebook were only allowed to participate 
in the survey. Therefore, a convenient random sampling technique was used to select a sample size of 156 consumers. The collected data were analyzed with the SPSS 20 version software and SMART PLS3, to understand the intention of the consumer to buying products through Facebook. After that output shows different charts, table, and figure.

\section{DATA ANALYSIS AND FINDINGS}

\section{A. Demographic Findings}

TABLE I: RESPONDENTS DEMOGRAPHIC PROFILE

\begin{tabular}{|c|c|c|c|}
\hline Profile & Groups & Frequency & Percentage (\%) \\
\hline \multirow[t]{2}{*}{ Gender } & Male & 79 & $50.75 \%$ \\
\hline & Female & 77 & $49.25 \%$ \\
\hline \multirow[t]{6}{*}{ Age } & $25-30$ & 78 & $50.1 \%$ \\
\hline & $31-35$ & 55 & $35.3 \%$ \\
\hline & $36-40$ & 17 & $11.0 \%$ \\
\hline & $41-45$ & 4 & $2.3 \%$ \\
\hline & $46-50$ & 2 & $1.30 \%$ \\
\hline & Above 50 & 0 & $0 \%$ \\
\hline \multirow{5}{*}{$\begin{array}{l}\text { Education } \\
\text { level }\end{array}$} & Below SSC & 0 & $0 \%$ \\
\hline & SSC & 2 & $1.5 \%$ \\
\hline & Higher Secondary & 25 & $15.3 \%$ \\
\hline & Graduation & 69 & $44.5 \%$ \\
\hline & Post-graduation & 60 & $38.7 \%$ \\
\hline \multirow[t]{4}{*}{ Profession } & Student & 66 & $42.0 \%$ \\
\hline & Service & 57 & $36.6 \%$ \\
\hline & Business & 11 & $6.9 \%$ \\
\hline & Other's & 23 & $14.5 \%$ \\
\hline \multirow{5}{*}{$\begin{array}{l}\text { Monthly } \\
\text { Income }\end{array}$} & $5000-15000$ & 28 & $18.0 \%$ \\
\hline & $16000-25000$ & 39 & $24.5 \%$ \\
\hline & $26000-35000$ & 36 & $23.0 \%$ \\
\hline & $36000-45000$ & 26 & $16.9 \%$ \\
\hline & 46000 above & 27 & $17.6 \%$ \\
\hline
\end{tabular}

Table 01 is demonstrating the demographic variables of the respondents surveyed. We see that from the total respondents $50.75 \%$ are male and $49.25 \%$ female. Almost $85.4 \%$ respondents are young, and they are aged between 25 years to 35 years. Data shows most of the respondents education level was in under graduate and post-graduation i.e. $83.2 \%$. Facebook has an influence to create purchase intention between students and service holders. There is a positive relationship between monthly income and influence of Facebook to create purchase intention among the peoples.

\section{B. Measurement model}

First, the model is run for the indicators and constructs reliability and validity under the measurement model. Then the path co-efficient is examined under the structural model. Becker et al. [5] suggested reporting indicator loadings, AVE, composite reliability, discriminant validity, multicollinearity of indicators etc.

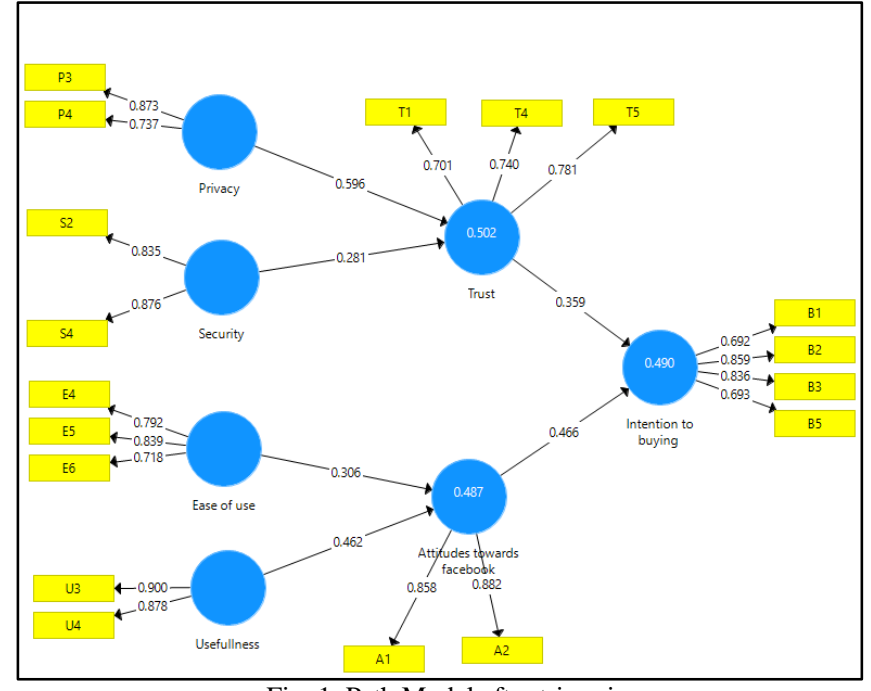

Fig. 1. Path Model after trimming

Construct validity and reliability of the reflective constructs: Based on the results of initial measurement model, twelve items with poor factor loadings were dropped, leaving total 18 items for the final analysis. All 18 standardized loadings are high and positively significant $(\mathrm{p}<0.05)$. Table II displays the constructs with composite reliability and AVE values and Cronbach's Alpha and items with standardized factor loading. The internal reliability can be evaluated considering Cronbach's alpha and composite reliability. A satisfactory reliable value will be between 0.60 and 0.95 [4], [18].

TABLE II: CONSTRUCT \& ITEMS WITH STANDARDIZED FACTORS LOADING

\begin{tabular}{|c|c|c|c|c|c|}
\hline \\
\hline Constructs & Items & $\lambda$ & AVR & CR & $\begin{array}{c}\text { Cronbach's } \\
\text { Alpha }\end{array}$ \\
\hline \multirow[b]{2}{*}{ Privacy } & P3 & 0.873 & \multirow[b]{2}{*}{0.653} & \multirow[b]{2}{*}{0.789} & \multirow[b]{2}{*}{0.707} \\
\hline & $\mathrm{P} 4$ & 0.737 & & & \\
\hline \multirow[b]{2}{*}{ Security } & S2 & 0.835 & \multirow[b]{2}{*}{0.732} & \multirow[b]{2}{*}{0.845} & \multirow[b]{2}{*}{0.710} \\
\hline & S4 & 0.876 & & & \\
\hline \multirow{3}{*}{ Ease of Use } & E4 & 0.792 & \multirow{3}{*}{0.615} & \multirow{3}{*}{0.827} & \multirow{3}{*}{0.727} \\
\hline & E5 & 0.839 & & & \\
\hline & E6 & 0.718 & & & \\
\hline \multirow[b]{2}{*}{ Usefulness } & U3 & 0.900 & \multirow[b]{2}{*}{0.791} & \multirow[b]{2}{*}{0.883} & \multirow[b]{2}{*}{0.736} \\
\hline & U4 & 0.878 & & & \\
\hline \multirow{3}{*}{$\begin{array}{c}\text { Attitude } \\
\text { towards } \\
\text { Facebook }\end{array}$} & A1 & 0.858 & \multirow{3}{*}{0.757} & \multirow{3}{*}{0.862} & \multirow{3}{*}{0.721} \\
\hline & A? & 0887 & & & \\
\hline & A2 & 0.002 & & & \\
\hline \multirow{3}{*}{ Trust } & $\mathrm{T} 1$ & 0.701 & \multirow{3}{*}{0.550} & \multirow{3}{*}{0.785} & \multirow{3}{*}{0.771} \\
\hline & $\mathrm{T} 4$ & 0.740 & & & \\
\hline & T5 & 0.781 & & & \\
\hline \multirow{4}{*}{$\begin{array}{l}\text { Intention to } \\
\text { buying }\end{array}$} & B1 & 0.692 & \multirow{4}{*}{0.599} & \multirow{4}{*}{0.855} & \multirow{4}{*}{0.773} \\
\hline & B2 & 0.859 & & & \\
\hline & B3 & 0.836 & & & \\
\hline & B5 & 0.693 & & & \\
\hline
\end{tabular}

$\lambda$, Standardized Factor Loadings; CR, composite reliability; AVE, average variance extracted.

Reliability estimates for each construct using composite reliabilities all exceed the threshold value of 0.70 [35]. Here, all the reflective constructs have a value above 0.7 that confirms strong internal reliability. Although Cronbach's alpha has been used widely in social science, it provides a conservative outcome for PLS-SEM; consequently, researchers suggested composite reliability as an alternative 
measure [55]. Also, table II demonstrates that the Cronbach's alpha (CA) values are considered satisfactory. The computed average variance extracted (AVE), also known as convergent validity, shows the degree of shared representation of items with constructs. All AVE values for each construct are acceptable as they exceed the recommended 0.50 value [4].

TABLE III: FORNELL-LARCKER CRITERIA OF DISCRIMINANT

\begin{tabular}{|l|c|c|c|c|c|c|c|}
\hline & $\begin{array}{c}\text { Attitudes } \\
\text { towards } \\
\text { Facebook }\end{array}$ & $\begin{array}{c}\text { Ease of } \\
\text { use }\end{array}$ & $\begin{array}{c}\text { Intention } \\
\text { to } \\
\text { buying }\end{array}$ & Privacy & Security & Trust & Usefulness \\
\hline $\begin{array}{l}\text { Attitudes } \\
\text { towards } \\
\text { Facebook }\end{array}$ & 0.870 & & & & & & \\
\hline $\begin{array}{l}\text { Ease of } \\
\text { use }\end{array}$ & 0.601 & 0.784 & & & & & \\
\hline $\begin{array}{l}\text { Intention } \\
\text { to buying }\end{array}$ & 0.620 & 0.629 & 0.774 & & & & \\
\hline Privacy & 0.182 & 0.277 & 0.281 & 0.808 & & & \\
\hline Security & 0.499 & 0.624 & 0.523 & 0.202 & 0.856 & & \\
\hline Trust & 0.427 & 0.518 & 0.559 & 0.653 & 0.402 & 0.741 & \\
\hline Usefulness & 0.657 & 0.637 & 0.720 & 0.308 & 0.512 & 0.549 & 0.889 \\
\hline
\end{tabular}

To test the discriminant validity we used the FornellLarcker criterion (1981). Fornell and Larcker used the square root of AVE, which should be larger than the latent variable correlations (LVC). Table III shows the square root of AVE, where each latent variable's value is greater than other LVC. It can be observed that items loading of the construct have a higher value than loading on other constructs. Both of these findings confirm the strong discriminant validity of the reflective constructs.

TABLE IV: INDICATORS WEIGHTS FOR FORMATIVE CONSTRUCTS

\begin{tabular}{|l|c|c|c|c|c|}
\hline & $\begin{array}{c}\text { Original } \\
\text { Sample } \\
(\mathrm{O})\end{array}$ & $\begin{array}{c}\text { Sample } \\
\text { Mean } \\
(\mathrm{M})\end{array}$ & $\begin{array}{c}\text { Standard } \\
\text { Deviation } \\
\text { (STDEV) }\end{array}$ & $\begin{array}{c}\text { T-Statistics } \\
(\mid \mathrm{O} / \mathrm{STDEV})\end{array}$ & $\begin{array}{c}\text { P- } \\
\text { Values }\end{array}$ \\
\hline $\begin{array}{l}\text { A1 <- Attitudes } \\
\text { towards } \\
\text { Facebook }\end{array}$ & 0.550 & 0.551 & 0.030 & 18.121 & 0.000 \\
\hline $\begin{array}{l}\text { A2<- Attitudes } \\
\text { towards } \\
\text { Facebook }\end{array}$ & 0.599 & 0.597 & 0.031 & 19.510 & 0.000 \\
\hline $\begin{array}{l}\text { B1 <- Intention } \\
\text { to buying }\end{array}$ & 0.264 & 0.263 & 0.031 & 8.600 & 0.000 \\
\hline $\begin{array}{l}\text { B2 <- Intention } \\
\text { to buying }\end{array}$ & 0.358 & 0.357 & 0.022 & 16.231 & 0.000 \\
\hline $\begin{array}{l}\text { B3 <- Intention } \\
\text { to buying }\end{array}$ & 0.348 & 0.348 & 0.024 & 14.252 & 0.000 \\
\hline $\begin{array}{l}\text { B5 <- Intention } \\
\text { to buying }\end{array}$ & 0.316 & 0.317 & 0.029 & 10.743 & 0.000 \\
\hline E4<- Ease of use & 0.410 & 0.408 & 0.037 & 11.065 & 0.000 \\
\hline E5 <- Ease of use & 0.408 & 0.406 & 0.034 & 11.904 & 0.000 \\
\hline E6<-Ease of use & 0.464 & 0.470 & 0.056 & 8.249 & 0.000 \\
\hline P3 <- Privacy & 0.712 & 0.709 & 0.071 & 9.982 & 0.000 \\
\hline P4 <- Privacy & 0.513 & 0.511 & 0.067 & 7.641 & 0.000 \\
\hline S2 <- Security & 0.545 & 0.543 & 0.066 & 8.311 & 0.000 \\
\hline S4 <- Security & 0.622 & 0.621 & 0.067 & 9.330 & 0.000 \\
\hline T1 <- Trust & 0.418 & 0.413 & 0.042 & 9.853 & 0.000 \\
\hline T4<- Trust & 0.373 & 0.370 & 0.045 & 8.295 & 0.000 \\
\hline T5 <- Trust & 0.553 & 0.562 & 0.060 & 9.175 & 0.000 \\
\hline U3<-Usefulness & 0.588 & 0.588 & 0.045 & 13.126 & 0.000 \\
\hline U4<-Usefulness & 0.536 & 0.535 & 0.035 & 15.315 & 0.000 \\
\hline
\end{tabular}

\section{Structural model}

After measurement model, the structural model needs to be evaluated to draw the conclusion. For formative constructs, we will evaluate three things: collinearity, coefficient of determination $\left(\mathrm{R}^{2}\right)$, and the path coefficient between the constructs.

TABLE V: MULTI-COLLINEARITY MEASUREMENT BY OUTER VIF VALUES

\begin{tabular}{|c|c|}
\hline & VIF \\
\hline A1 & 1.362 \\
\hline A2 & 1.362 \\
\hline B1 & 1.492 \\
\hline B2 & 2.222 \\
\hline B3 & 1.956 \\
\hline B5 & 1.314 \\
\hline E4 & 1.700 \\
\hline E5 & 1.824 \\
\hline E6 & 1.153 \\
\hline P3 & 1.110 \\
\hline P4 & 1.110 \\
\hline S2 & 1.277 \\
\hline S4 & 1.277 \\
\hline T1 & 1.219 \\
\hline T4 & 1.315 \\
\hline T5 & 1.154 \\
\hline U3 & 1.512 \\
\hline U4 & 1.512 \\
\hline & \\
\hline
\end{tabular}

TABLE VI: MULTI-COLLINEARITY MEASUREMENT BY INNER

\begin{tabular}{|l|c|c|c|}
\hline & $\begin{array}{c}\text { VIF VALUES } \\
\text { Attitudes } \\
\text { towards } \\
\text { Facebook }\end{array}$ & $\begin{array}{c}\text { Intention } \\
\text { to buying }\end{array}$ & Trust \\
\hline $\begin{array}{l}\text { Attitudes towards } \\
\text { Facebook }\end{array}$ & 1.683 & 1.223 & \\
\hline Ease of use & & & \\
\hline Privacy & & 1.043 \\
\hline Security & & 1.223 & \\
\hline Trust & 1.683 & & \\
\hline Usefulness & & & \\
\hline
\end{tabular}

Collinearity assessment: Collinearity is assessed by variance inflation factor (VIF), for which a value of 5 or above typically indicates problem [17]. However, a maximum, the VIF for formative factors should be below 10 , but for a more rigorous test, they should be below 3.30 [38]. Collinearity assessment of our model shows that all the construct values of independent variables are below 3.30 (see Table V \& VI).

TABLE VII: VALUE OF CO-EFFICEINT OF DETEMINATION $\left(\mathrm{R}^{2}\right)$
\begin{tabular}{|l|c|c|}
\hline & R Square & R Square Adjusted \\
\hline Attitudes towards & 0.487 & 0.481 \\
Facebook & & 0.483 \\
\hline Intention to buying & 0.490 & 0.495 \\
\hline Trust & 0.502 & \\
\hline
\end{tabular}

The co-efficient of determination $\left(R^{2}\right): R^{2}$ is a major part of a structural model evaluation. $\mathrm{R}^{2}$ value of $0.25,0.50$, and 0.70 are referred to as a weak, moderate, and strong coefficient of determination, respectively [18]. In our model, attitudes towards Facebook and trust are found to explain $48.7 \%$ and $50.2 \%$ of variances of the create intention to buying through Facebook respectively. In overall these two 
construct are $\left(\mathrm{R}^{2}=0.502\right)$ accountable to explain the dependent variable (see figure 1) in this PLS-SEM model.

Path co-efficient: Path coefficients in the PLS-SEM are tested for the relationship between constructs and significance level. Table VIII shows that attitudes towards Facebook strongly affects by ease of use and usefulness $(\beta=$ $0.306, \mathrm{t}=3.83, \mathrm{p}<0.05$ and $\beta=0.462, \mathrm{t}=4.989, \mathrm{p}<0.05)$ respectively. Also, privacy $(\beta=0.596, \mathrm{t}=8.78, \mathrm{p}<0.05)$ and security $(\beta=0.281, \mathrm{t}=3.659, \mathrm{p}<0.05)$ has strong significant effect on trust. Finally, from table 8 we will get clear findings about the above hypotheses. The hypotheses can be tested by using the significance of the standardized path coefficients which can be is assessed by the bootstrap tvalues which should be higher than 2 [9]. From the following table (see table VIII) we can see the t-value for the path of H5 is 6.224 and H6 6.435 which are far above the standard value. So this study supports both of our hypotheses which focus on the fact that both trust and attitudes towards Facebook will lead to greater intent to change the buying behavior.

TABLE VIII: SIGNIFICANCE TESTING RESULTS OF THE STRUCTURAL MODEL PATH CO-EFFICIENTS

\begin{tabular}{|l|c|c|c|c|c|}
\hline & $\begin{array}{c}\text { Original } \\
\text { Sample } \\
(\mathrm{O})\end{array}$ & $\begin{array}{c}\text { Standard } \\
\text { Deviation }\end{array}$ & $\begin{array}{c}\text { T Statistics } \\
(\mid \mathrm{O} / \text { STDEV })\end{array}$ & $\begin{array}{c}\mathrm{P} \\
\text { Values }\end{array}$ & Hypothesis \\
\hline $\begin{array}{l}\text { Attitudes } \\
\text { towards }\end{array}$ & 0.466 & 0.072 & 6.435 & 0.000 & Accepted \\
$\begin{array}{l}\text { Facebook - } \\
>\text { Intention } \\
\text { to buying }\end{array}$ & 0.306 & 0.080 & 3.830 & 0.000 & Accepted \\
\hline $\begin{array}{l}\text { Ease of } \\
\text { use -> } \\
\text { Attitudes } \\
\text { towards } \\
\text { Facebook }\end{array}$ & 0.596 & 0.068 & 8.780 & 0.000 & Accepted \\
\hline $\begin{array}{l}\text { Privacy -> } \\
\text { Trust }\end{array}$ & 0.281 & 0.077 & 3.659 & 0.000 & Accepted \\
\hline $\begin{array}{l}\text { Security -> } \\
\text { Trust }\end{array}$ & 0.359 & 0.058 & 6.224 & 0.000 & Accepted \\
\hline $\begin{array}{l}\text { Trust -> } \\
\text { Intention } \\
\text { to buying }\end{array}$ & 0.462 & 0.093 & 4.989 & 0.000 & Accepted \\
\hline $\begin{array}{l}\text { Usefulness } \\
-> \\
\text { Attitudes } \\
\text { towards } \\
\text { Facebook }\end{array}$ & 0 & & & & \\
\hline
\end{tabular}

\section{DISCUSSION AND CONCLUSION}

From this study, the authors have found that all the constructs and sub-constructs support the reliability of the measures. All the constructs and sub-constructs are satisfying all the reliability and validity tests. In this study, the authors have used two independent constructs. Between the two independent constructs, attitudes towards Facebook has the largest effect on the change the buying behavior and, trust has a smaller effect on the dependent variable that is the intention to change the buying behavior. So, the change the buying behavior through Facebook largely depends upon the accumulative structure of all sub-constructs. The structural model in PLS was assessed by examining the standardized path coefficients. The PLS path coefficients are shown in Figure 1. The findings support all hypotheses (see Fig. 1) of the model (see table VIII). Approximately $49 \%$ of the variance in change the buying through Facebook is accounted for by these two constructs (trust and attitudes towards Facebook) in the model. The standardized path coefficients range from 0.466 to 0.359 , exceeding the suggested minimum standard of significance at 0.20 [9]. Thus, the fit of the overall model is good. Through empirical research in this paper, it is found that - ease of use and usefulness have significantly positive impacts on the intention to buy. These impacts are not only indirect effects but can also have direct impacts on attitudes towards Facebook, while attitudes towards Facebook have a positive impact on the change the buying behavior. As well as, privacy and security have significant influences on trust whereas trust has a positive influence on change the buying behavior. Therefore, increasing use of social media worldwide has led to the belief that this is a valuable tool in supporting consumer engagement. Because companies are continually looking to new methods for reaching consumers and for shaping consumer behaviors, including brand loyalty and intention to buy. This is possible only when companies ensure the trust that will build if consumers fell secure and get privacy. As well as, require to develop attitudes among the consumers.

\section{REFERENCES}

[1] Ajzen, I., Fishbein, M., (1980). Understanding Attitudes and Predicting Social Behavior. Englewood Cliffs, NJ: Prentice-Hall.

[2] Ajzen, I., 1985. From Intentions to Actions: A Theory of Planned Behavior. In: Kuhl, J. \& Beckman, J. (Eds.). Action-Control: From Cognition to Behavior (pp. 11-39). Heidelberg, Germany: Springer.

[3] Andriole, S. 2010. Business impact of Web2.0 technologies. Journal of Communication 53(12), 67-79.

[4] Bagozzi, R. P., \& Yi, Y. (1988). On the evaluation of structural equation models. Journal of the Academy of Marketing Science, 16, 74-94. doi:10.1007/bf02723327.

[5] Becker, J. M., Klein, K., \& Wetzels, M. (2012). Hierarchical latent variable models in PLS-SEM: Guidelines for using reflectiveformative type models. Long Range Planning, 45, 359-394. doi:10.1016/j.lrp.2012.10.001

[6] Berthon, P.R., Pitt, L.F., Plangger, K \& Shapiro, D. 2012. Marketing meets Web 2.0, social media, and creative consumers; implications for international marketing strategy. Business Horizon, 55 (3), 261 71.

[7] Ballantine, W.P \& Stephenson, J. R. (2011). Help me, I'm fat! Social support in online weight loss networks. Journal of Consumer Behavior, 10: 332-337.

[8] Chen, J., Xu, H. 8c Whinston, A.B. (2011a). Moderated online communities and quality of user-generated content. Journal of Management Information Systems, 28 (2), 237-268.

[9] Chin, W. W. (1998). "Issues and Opinion on Structure Equation Modeling", MIS Quarterly, Vol. 22, pp.vii-xvi.

[10] Chuttur, M.,(2009). Overview of the Technology Acceptance Model: Origins, developments and future directions. Working Papers on Information Systems, 9-37.

[11] Davis, F. D., (1989). Perceived Usefulness, Perceived Ease of Use, and User Acceptance of Information Technology. Management Information Systems Quarterly, 13(3), 319-340.

[12] Fornell, C., Larcker, D.F. (1981). Evaluating structural equation models with unobservable variables and measurement error. Journal of Marketing Research, 18 (1), 39-50.

[13] Gong, W., Stump, R. L., Maddox, L. M., (2013). Factors influencing consumers' online shopping in China. Journal of Asia Business Studies, 7(3), 214-230.

[14] Gruzd,A. Wellman ,B .\& Takhteyev,Y. (2011). Imagining Twitter as an Imagined Community. American Behavioral Scientist, 55: 1294

[15] Goldstein, M. (1998). The Asian Financial Crisis: Causes, Cures, and Systematic Implications, Institute of International Economics: Washington, DC., 77 pages, ISBN 0-88132-261-X.

[16] Giri.N. \& Christopher,B,S.(2015).Impact of Facebook on the Buying Behaviour of Students. International Journal of Advance Research in computer science and Management studies. 3 (11). 
[17] Hair, J. F., Ringle, C. M., \& Sarstedt, M. (2011). PLS-SEM: Indeed a silver bullet. The Journal of Marketing Theory and Practice, 19, 139-152. doi:10.2753/MTP1069-6679190202.

[18] Hair, J. F., Hult, G. T. M., Ringle, C. M., \& Sarstedt, M. (2013). A primer on partial least squares structural equation modeling (PLS SEM). Qualitative research, 6. Thousand Oaks, CA: SAGE Publications, Inc. doi: 10.1177/1468794106058877.

[19] Hyung, D.; Lee, J.; \& Han, I. (2007). The effect of online consumer reviews on consumer purchasing intention: the moderating role of involvement, International Journal of Electronic Commerce, 11(4). Pp.125-148.

[20] Heijden,H.V.D; Verhagen, T.; \& Creemers,M.(2003). Understanding online purchase intentions: contributions from technology and trus perspectives, European Journal of Information Systems, 12. Pp. 4148. doi:10.1057/ palgrave.ejis.3000445.

[21] Heijden, H.V.D. \& Verhagen, T. (2002). Measuring and Assessing Online Store Image: A Study of Two Online Bookshops in the Benelux, Proceedings of the $35^{\text {th }}$ Hawaii International Conference on System Sciences. Hawaii.

[22] Kim, E., Hong, T., (2010). Segmentating Customers in Online Stores from Factors that Affect the Customer's Intention to Purchase, pp. 383-388.

[23] Kim, H., Song, J., (2010). The Quality of Word-of Mouth in the Online Shopping Mall. Journal of Research in Interactive Marketing, 4(4), 376-390.

[24] Kazaeniac, A. (2009). Social networks: Facebook takes over top shot, twitter climb. Retrieved from http://blog.compete.com/20 09/02/09/facebook-myspace-twitter-social-network/ on 12th November, 2010.

[25] Kara, Y. \& Coşkun, A. C. (2012). Sosyal Ağların Pazarlama Aracı Olarak Kullanımı Örneği, Afyon Kocatepe Üniversitesi, İIBF Dergisi, 16(2), 73-90. Access date: 05 February 2016.

26] Kaplan,M,A \& Haenlein,M (2010) .Users of the world ,unite! The challenges and opportunities of Social Media. Business Horizons.53, 59-68.

[27] Kohli, C., Suri, R., \& Kapoor, A. (2014). Will social media kill branding? Business Horizons, 1171, 1-10. DOI: 10.1016/j.bushor.2014.08.004.

[28] Liu, Y., Chen, Y., Zhou, C. F., (2010). Determinants of Customer Purchase Intention in Electronic Service. Institute of Electrical and Electronics Engineers.

[29] Lu, P.H.\& Hsiao,L.K. (2010) The influence of extro/introversion on the intention to pay for social networking sites ,Information \& Management, 47 (3), pp. 150-157

[30] Liang, T.-P. \& Turban, E. (2011). Introduction to the special issue social commerce: a research framework for social commerce. International Journal of Electronic Commerce, 16 (2), 5-14.

[31] Mclure, M. W.; \& Samer,F .(2005). Why should I share? Examinig social capital and knowledge contribution in electronic networks of practice. MIS Quarterly, 29(1). Pp. 35-57.

[32] Muntinga, D., Moorman, M., \& Smit, E. (2011). Introducing COBRAs: Exploring motivations for brand-related social media use. International Journal of Advertising, 30 (1), 13-46.

[33] Mangold G. and Faulds D., (2009). Social media: The new hybrid element of the promotion mix, Business Horizons, 52. Pp. 357-365.

[34] Mangold, W.G. and Faulds, D.J. (2009) Social Media: The New Hybrid Element of the Promotion Mix. Business Horizons, 52, 357 365. http://dx.doi.org/10.1016/j.bushor.2009.03.002.

[35] Nunnally, J., Bernstein, I. (1994). Psychometric Theory. New York: McGraw-Hill.

[36] Nolcheska, V. (2017). The Influence of Social Networks on Consumer Behavior. Balkan and Near Eastern. Journal of Social Sciences, 3 (4), 75-87.

[37] Nelson-Field, K., Riebe, E. \& Sharp, B. (2012). What's Not to "Like?" Can a Facebook Fan Base Give a Brand the Advertising Reach It Needs?, Journal of Advertising Research, 52(2), pp.262269.

[38] Petter, S., Straub, D. W., \& Rai, A. (2007). Specifying formative constructs in information systems research. MIS Quarterly, 31, 623656.

[39] Pookulangara,S \& Koesler,K. (2011) Cultural influence on consumers' usage of social networks and its' impact on online purchase intentions. Journal of Retailing and Consumer Services 18(4):348-354.

[40] Peng, H., Wang, C., Cai, J.,( 2008). An empirical investigation on the adoption of online hopping of university students in China. International Seminar on Business and Information Management. pp. 498-501. Wuhan: Wuhan University.

[41] Pütter, M. (2017). The Impact of Social Media on Consumer Buying Intention. Journal of International Business Research and
Marketing, 3(1), pp.7-13. DOI: $\quad$ 10.18775/jibrm.1849 8558.2015.31.3001.

[42] Quelch, J. A., \& Jocz, K. E. (2008). Milestones in marketing. Business History Review, 82 (4), 827-838.

[43] Rana, A. (2018). Facebook Marketing and its Influence on Consumer Buying Behaviour in Kathmandu. Journal of Business and Social Sciences Research, 1(1), 111-128. https://doi.org/10.3126/jbssr.v1i1.20952.

[44] Richard P. Bagozzi. (2007). The Legacy of the Technology Acceptance Model and a Proposal for a Paradigm Shift. Journal of the Association for Information System, 8(4), 244-254.

[45] Richard,E.j.; Guppy, S. (2014). Facebook: Investigating the influence on consumer purchase intention, Asian Journal of Business Research, 4(2). Pp.1-15. DOI 10.14707/ajbr.140006.

[46] Rowley, J. 2004. Just Another channel? Marketing Communication in e business. Marketing Intelligence and Planning, 22 (1), 24-41.

[47] Roca, J. C., Garcia, J. J., Vega, J. d., (2009). The Importance of Perceived Trust, Security and Privacy in Online Trading Systems. Information Management and Computer Security, 17(2), 96-113.

[48] Sing,R. (2016). A STUDY OF CUSTOMER'S BEHAVIOR TOWARDS SOCIAL MEDIA MARKETING. International Journal of Advance Research and Innovative Ideas in Education, 2 (4). Pp 2395-4396.

[49] Safko, L. \& Brake, D.K. (2009). The Social Media Bible: Tactics, Tools, and Strategies for Business Success. $3^{\text {rd }}$ edition. New Jersey: John Wiley \& Sons, Inc.

[50] Su, S. (2010). Facebook's Spanish-language market marked by fragmentation, but promises opportunity. Retrieved from http://www.insidefacebook.com.htm on 12th October, 2010.

[51] Senecal, S. \& Nantel, J. (2004). The influence of online product recommendations on consumers' online choices. Journal of Retailing, 80 (2), 159-169.

[52] Simon, C., Brexendorf, T.O. \& Fassnacht, M. (2013) .Creating Online Brand Experience on Facebook. Mark Rev St. Gallen 30(6). pp 50-59|

[53] Venkatesh, V., Davis, F.D., (2000). "A theoretical extension of the Technology Acceptance Model: Four Longitudinal Field Studies," Management Science, 46. 186-204.

[54] Wasko,M,M \& Faraj,S. (2005). Why Should I Share? Examining Social Capital and Knowledge Contribution in Electronic Networks of Practice. MIS Quarterly. 29 (1), Special Issue on Information Technologies and Knowledge Management (Mar., 2005), pp. 35-57.

[55] Wong, K. K. (2013). Partial least squares structural equation modeling (PLS-SEM) techniques using smart PLS. Marketing Bulletin, 24(1), 1-32. doi:10.1108/EBR-10-2013-0128.

[56] Yass K. Salih, Ong Hang See and Rabha W. Ibrahim2 (2016). An intelligent selection method based on game theory in heterogeneous wireless networks. Wiley Online Library.27:1641-1652.

[57] Yusniza, K., (2007). Adoption of travel e-shopping in the UK International Journal of Retail \& Distribution Management, 35(9), 703-719.

[58] Zarrella, D. (2010). The Social Media Marketing. Sebastopol 1005 Graven stein Highway North: O'Reilly Media, Inc, 2010, pp. 3.

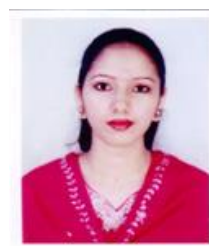

Shakila Jahan Nipa is Senior Lecturer, Department of Business Administration at the Daffodil Institute of Information and Technology(DIIT), Dhaka, Bangladesh. She finished Bachelor of Business Administration, major in Marketing, from National University of Bangladesh and holds MBA from Institute of Science Trade and Tecnology(ISTT). She published two books. Nipa's area of interest includes Social Marketing, Social marketing promotion, Consumer Behavior and Technology in Marketing.

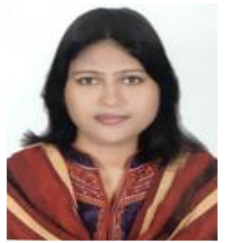

Fahmida Akter is Lecturer, Department of Business Administration at the Daffodil Institute of Information and Technology(DIIT), Dhaka, Bangladesh. She finished Bachelor of Business Administration, major in Finance, from National University of Bangladesh and holds MBA from Daffodil International University, Bangladesh, major in Finance. Akter's area of interest includes Public finance, Banking, Financial Inclusion and Fintech. 


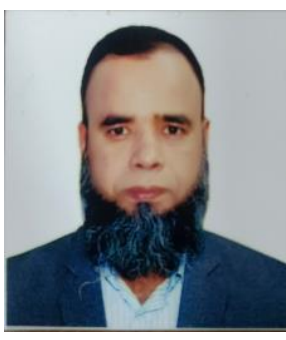

Dr. Mohammed Shakhawat Hossain, has more than 18 years hardcore experience in education and 4 years' experience as the deputy manager in an insurance company, Bangladesh He also worked as the coordinator of Business faculty for two and half years in a private university, Bangladesh.

He holds a DBA degree from Institute of Business Administration (IBA) under Dhaka University, Bangladesh. $\mathrm{He}$ is currently working as an Associate Professor \& Principal at the Daffodil Institute of Information and Technology (DIIT), Dhaka, Bangladesh. He has published several local and international papers in reputable journals and also attended both local and international conferences. Previously, he finished Bachelor degree, major in Finance, from University of Dhaka, Bangladesh and holds M.com \& MBA from University of Dhaka, Bangladesh, major in Banking \& Marketing respectively. His research interests are Blue Ocean Strategy, Financial Inclusion, Mobile Financial Services, and Emerging Capital Markets. 